\title{
Breastfeeding and the nutritional transition in the Latin American and Caribbean Region: a success story?
}

\author{
Amamentação e transição nutricional na América \\ Latina e Caribe: um caso bem-sucedido?
}

Rafael Pérez-Escamilla 1

\footnotetext{
1 Department of Nutritional Sciences, University of Connecticut. Storrs, CT, 06269, U.S.A. rperez@canr.uconn.edu
}

\begin{abstract}
The objectives of this paper are to examine recent breastfeeding duration trends in Latin America and the Caribbean to document: (a) rural-urban differentials, (b) differences in educational levels, and (c) changes in breastfeeding duration across time. Secondary data analyses were conducted with 23 Demographic and Health Surveys collected between the mid-1980s and mid-1990s. Results indicate that median breastfeeding duration is still greater in rural (as compared to urban) areas and among less (versus more) educated women, although these differentials are decreasing with time. In five of the six countries examined for secular trends, breastfeeding duration continues to increase in both rural and urban areas. Breastfeeding duration in urban and rural areas was strongly correlated within countries. Breastfeeding duration improved more among women with the highest and declined among those with the lowest level s of education. Results indicate that breastfeeding duration has increased in Latin America and the Caribbean at a time when the opposite was predicted, gi ven the region's increased urbanization. Breastfeeding protection policies and promotion programs may explain part of the increase in breastfeeding duration.
\end{abstract}

Key words Breastfeeding; Demography; Nutritional Transition

Resumo Os obj etivos deste artigo incluem examinar tendências recentes na duração da amamentação na América Latina e Caribe e documentar: (a) diferenciais entre áreas rurais e urbanas, (b) diferenças em escolaridade materna e (c) mudanças na duração do alei tamento materno ao longo do tempo. Foram realizadas análises de dados secundários a partir de 23 pesquisas demográficas em saúde conduzi das entre meados das décadas de 80 e 90 . Os resultados indicam que a duração mediana da amamentação continua sendo maior nas áreas rurais comparadas com as urbanas e entre mulheres com menos escolari dade, embora tais diferenças estejam di minuindo ao longo do tempo. Em cinco dos seis países estudados em rel ação a tendências seculares, continua aumentando a duração da amamentação, tanto em áreas rurais quanto urbanas. A duração da amamentação em áreas urbanas e rurais estava fortemente correlacionada dentro dos países. A duração do al ei tamento aumentou mais entre mulheres com maior escolaridadee declinou entre mulheres com menor escol aridade. Os resultados indicam que a duração do alei tamento vem aumentando na América Latina e Caribe numa época em que era previsto o oposto, em vista da crescente urbanização da região. Políticas de proteção ao al ei tamento materno e programas de promoção podem explicar parte do aumento na duração do al ei tamento materno. Palavras-chave Aleitamento Materno; Demografia; Transição Nutricional 


\section{Introduction}

The nutrition transition in developing countries can be defined as a process that involves the coexistence of nutritional imbalances and health-related conditions linked with underand over-nutrition (and often with a sedentary life-style). This phenomenon has major implications for the health care systems of Latin America and the Caribbean Region where the incidence of obesity (Peña \& Bacallao, 2001; Popkin, 2001) and obesity-related chronic diseases - e.g., heart disease (Yusuf et al., 2001), diabetes type 2 (Barceló \& Rajpathak, 2001) has increased dramatically at the same time that infectious diseases in children (e.g., pneumonia, diarrhea) continue to be a major public health problem even though their incidence has declined substantially in the past decades (Yusuf et al., 2001).

For a number of reasons, breastfeeding epidemiology is crucial for our understanding of health outcomes shaped by the nutrition transition currently under way in the Latin American and Caribbean Region. This is because breastfeeding is associated with protection against both infectious and chronic conditions. For example, at the same time that breastfeeding offers protection against upper respiratory (Cesar et al., 1999) and gastro-intestinal tract (Brown et al., 1989) infections, it may also protect against the onset of obesity (Dietz, 2001). By the same token, breastfeeding protects women against severe post-partum hemorrhages and may protect them against pre-menopausal breast cancer (Labbok, 1999).

On the one hand, national ly representative data from the Latin American and Caribbean Region has shown that: (a) within countries, breastfeeding is more prolonged in rural than in urban areas and among women with lower rather than higher levels of formal education (Pérez-Escamilla et al., 1994; Trussell et al., 1992), and (b) among countries, those with a higher proportion of their population living in rural areas present more exten ded breastfeeding when compared with more urbanized nations (Pérez-Escamilla, 1994; Trussell et al., 1992). On the other hand, nationally representative data also show that in the last decades, the countries in our region have become more urbanized and women have achieved higher levels of formal education and are more likely to be employed outside of their households. Thus, it would be reasonable to expect for breastfeeding to decrease in duration within countries across time. Unexpectedly however, epidemiological data have consistently shown that breastfeeding duration in Latin American and Caribbean countries has increased from the 1970 s to the 1980s in most countries examined (Elo \& Grummer-Strawn, 1993; GrummerStrawn, 1996; Trussell et al., 1992). A similar upward trend for this period has been reported in the City of São Paulo (M onteiro et al., 1987) and for Brazil as a whole (Venâncio \& Monteiro, 1998).

The objective of this article is to: (a) analyze recent nationally representative data to learn whether the upward breastfeeding trend detected from 1970s to 1980s continued during the 1990s, (b) if confirmed, to provide possible explanations for these increases in spite of all the potential downward forces on breastfeeding that characterize the nutrition transition (e.g., more urbanization and higher maternal employment and level of education), and (c) discuss implications of breastfeeding trends for the nutrition transition.

\section{Methods and statistical analyses}

The Demographic and Health Surveys (DHS) program assists developing countries in conducting national population and health surveys. The program is funded primarily by the United States Agency for International Development (USAID) and is administered by Macro International Inc. in Calverton, Maryland (Institute for Resource Development/ Macro International, 1990). The DHS surveys target childbearing-age women (i.e., 15-49 years of age in most surveys) and are designed to generate nationally representative data on infant feeding practices, population and family planning, and various maternal and child health outcomes (Institute for Resource Development/ Macro International, 1990). DHS sampling frameworks are based on complex stratified sampling designs. Strict training and quality-control procedures are followed in all countries conducting DHS surveys (Institute for Resource Development/M acro International, 1991).

DHS replaced the World Fertility Surveys (WFS) as one of the most reliable sources for tracking infant feeding and family planning data worldwide. Whereas WFS were conducted in the 1970s, DHS-I surveys were collected in the 1980s, and DHS-II and DHS-III surveys began to be collected in the early 1990s. A core infant feeding module is applied in all countries to women with children under three years of age.

All DHS surveys conducted in the Latin American and Caribbean Region and available online as of February 2002 were analyzed online using STAT (http:// www.measuredhs.com). 
Analyses were based on 23 surveys distributed across 12 countries (Table 1 ). These included: Bolivia ( $\mathrm{n}=3$ surveys), Brazil ( $\mathrm{n}=2$ national surveys), Colombia ( $\mathrm{n}=3$ surveys), Dominican Republic ( $n=3$ surveys), Ecuador ( $n=1$ survey), Guatemala ( $n=3$ surveys), Haiti ( $n=1$ survey), Mexico ( $n=1$ survey), Nicaragua ( $n=1$ survey), Paraguay ( $n=1$ survey), Peru ( $n=3$ surveys), and Trinidad and Tobago ( $n=1$ survey). Breastfeeding duration results and sample sizes were checked for inconsistencies, and in two instances required correction or clarification from DHS-STAT personnel. In the case of Mexico1997, the computed median breastfeeding duration and sample sizes for urban and rural areas were incorrect and had to be re-estimated using the appropriate classification for area of residence. Guatemala-1987 required clarification, as estimated duration for "any breastfeeding" was identical to that reported for exclusive breastfeeding. The error was with the exclusive breastfeeding estimates, and the any-breastfeeding data presented in this article were confirmed as correct.
All of the surveys included women from 15 to 49 years of age with sample sizes ranging from 3,806 in Trinidad and Tobago-1987 to 28,951 in Peru-1996. Data collection years ranged from 1986 to 1999 (Table 1). Median breastfeeding duration for women with children less than three years of age was computed for each country based on current status breastfeeding "survival" curves (i.e., whether infant was breastfed or not at the time of the survey plotted across time - child age). Median BF durations generated by STAT were exported into Excel and subsequently read as an SPSS for Windows file (version 10.07). This software was used to compare within-countries' breastfeeding duration as a function of area of residence (urban, rural) and levels of maternal education (none, primary, secondary, or higher). Secular trends in BF duration were examined across time in the six countries with more than one DHS (Bolivia, Brazil, Colombia, Dominican Republic, Guatemala, and Peru). Within-country secular trend comparisons were based on comparing BF duration between the first and last survey wave, $a$

Table 1

Demographic and Health Surveys conducted in 12 Latin American and Caribbean countries among women 15 to 49 years old.

\begin{tabular}{|c|c|c|c|}
\hline Country/survey year & $\mathrm{N}$ & Starting date (month/year) & Final date (month/year) \\
\hline Bolivia 1989 & 7,923 & February/1989 & J uly/1989 \\
\hline Bolivia 1994 & 8,603 & November/1993 & May/1994 \\
\hline Bolivia 1998 & 11,187 & March/1998 & September/1998 \\
\hline Brazil 1986 & 5,892 & May/1986 & August/1986 \\
\hline Brazil 1996 & 12,612 & March/1996 & J une/1996 \\
\hline Colombia 1986 & 5,329 & October/1986 & December/1986 \\
\hline Colombia 1990 & 8,644 & May/1990 & August/ 1990 \\
\hline Colombia 1995 & 11,140 & March/1995 & J une/1995 \\
\hline Dominican Republic 1986 & 7,649 & September/1986 & December/1986 \\
\hline Dominican Republic 1991 & 7,320 & J uly/1991 & November/1991 \\
\hline Dominican Republic 1996 & 8,422 & September/1996 & December/1996 \\
\hline Ecuador 1987 & 4,713 & J anuary/1987 & March/1987 \\
\hline Guatemala 1987 & 5,160 & October/1987 & December/1987 \\
\hline Guatemala 1995 & 12,403 & J une/1995 & December/1995 \\
\hline Guatemala 1998 & 6,021 & November/1998 & April/1999 \\
\hline Haiti 1994 & 5,356 & J uly/1994 & J anuary/1995 \\
\hline Mexico 1987 & 9,310 & February/1987 & M ay/1987 \\
\hline Nicaragua 1997 & 13,634 & December/1997 & May/1998 \\
\hline Paraguay 1990 & 5,827 & May/1990 & August/1990 \\
\hline Peru 1986 & 4,999 & September/1986 & December/1986 \\
\hline Peru 1992 & 15,882 & October/1991 & March/1992 \\
\hline Peru 1996 & 28,951 & August/1996 & November/1996 \\
\hline Trinidad \& Tobago 1987 & 3,806 & May/1987 & August/1987 \\
\hline
\end{tabular}


period of time that spanned about 10 years and referred to in this paper as "from the mid-1980s to the mid-1990s". SPSS for Windows (version 10.07) was used to determine the BF duration's Pearson's correlation coefficient by area of residence and level of education.

The Brazil-1996 data set was downloaded from the Internet (http://www.measuredhs. com) and read as an SPSS for Windows data file. This statistical software was used to examine the relationship between maternal education and the likelihood of BF initiation (ever/ never-breastfed) using the chi-square test and a maximum 2-sided probability value of 0.05 as the criterion for statistical significance.

\section{Results}

Analyses demonstrated a wide variation in median breastfeeding duration across countries ranging from 5.2 months in Brazil 1986 to 20.5 months in Guatemala-1987. Women in countries with the highest percent of rural population in the sample tended to breastfeed longer. Guatemala had both the highest median duration of breastfeeding as well as the highest percentage of rural population. By contrast, Brazil, Mexico, and Colombia, which had the lowest percent of rural populations included in the survey samples tended to have the lowest median BF duration in the 1980s (5.2 months, 8.1 months, and 8.2 months, respectively). Longer breastfeeding in more rural countries was not universal, as for example Peru had one of the longest median breastfeeding figures (15.4 months in 1986 to 19.5 months in 1996), even though the country is predominantly urban. By contrast, Trinidad and Tobago-1987, which included a predominantly rural sample, had a median BF duration of only 6 months (Table 2 ).

Breastfeeding duration as a function of area of residence and level of education

In all but one country (Trinidad and Tobago1987), median breastfeeding duration was longer in rural (range: 5.8 months in Trinidad and Tobago- 1987 to 20.8 months in Guatemala-1987) than in urban areas (range: 4.6 months in the Dominican Republic-1991 and Brazil1986 to 19.1 in Guatemala-1987). This rural-urban (R-U) differential ranged from -0.6 months in Trinidad and Tobago-1987 to 8.9 months in Mexico-1987 (Table 2). There was a strong within-country correlation between BF durations in rural and urban areas (Pearson's $r=0.89, p<$ $0.001, \mathrm{n}=23$ )
In all but one survey (Brazil-1996), breastfeeding duration was greater among women with no schooling (range: 5.8 months in Brazil1996 to 22.5 months in Peru-1986) than among women with at least secondary education (range: 4.1 months in the Dominican Republic1991 to 18.3 months in Peru-1986). This educational level differential (N-S) ranged from - 1.5 months in Brazil-1996 to 13.7 months in Mexico-1987 (Table 3). There was a significant within-country correlation between BF duration among women with no schooling and women with at least a secondary education (Pearson's $r=0.61, p=0.001, n=23$ ). In Brazil, level of education was also positively associated with the likelihood of BF initiation (Figure 1).

\section{Breastfeeding duration as a function of time}

Five of the six countries with more than one DHS survey experienced increases in BF duration from the mid-1980s to the mid-1990s (BF delta range: +0.5 months in the Dominican Republic to +4.1 months in Peru). During this period, Guatemala experienced a slight decline in BF duration, from 20.5 months to 19.9 months (Table 2).

\section{- Area of residence}

In rural areas, Guatemala was the only one of the six countries not experiencing an increase in BF duration from the mid-1980s to the mid1990s (BF delta range: -0.4 months in Guatemala to 3.1 months in the Dominican Republic). In urban areas, Guatemala and the Dominican Republic experienced slight declines in BF duration from the mid-1980s to the mid-1990s (-0.5 months and -0.7 months, respectively). The remaining countries experienced positive changes in BF duration in these urban areas ( +7.8 months in Peru, +3.9 months in Colombia, and +2.1 months in both Brazil and Bolivia). In short, from the mid-1980s to the mid1990s, five of the six countries examined for secular trends experienced positive changes in BF duration in the whole country, five in rural areas, and four in urban areas. Four countries (Bolivia, Brazil, Colombia, and Peru) experienced positive increases during this period in BF duration both in urban and rural areas, with improvements more pronounced in urban than in rural areas (Table 2 ).

In three countries (Bolivia, Colombia, and Peru), the rural-urban BF differential decreased in the mid-1990s as compared to the mid-1980s ((R-U) BF delta range: -7.0 months in Peru to 0.5 months in Bolivia). In Guatemala and the 
Breastfeeding (BF) time trends and differentials based on area of residence in 12 Latin American and Caribbean countries. Current status estimates based on children less than three years of age.

\begin{tabular}{|c|c|c|c|c|c|c|c|c|c|c|}
\hline $\begin{array}{l}\text { Country/ } \\
\text { survey year }\end{array}$ & $\mathrm{n}^{1}$ & Rural $(\%)^{2}$ & $\begin{array}{l}\text { BF Median } \\
\text { (mo })\end{array}$ & $\begin{array}{l}\text { BF Delta3 } \\
\text { (mo) }\end{array}$ & $\begin{array}{c}\text { Rural BF } \\
\text { median } \\
(\mathrm{mo})\end{array}$ & $\begin{array}{c}\text { Rural BF } \\
\text { Delta3 } \\
\text { (mo) }\end{array}$ & $\begin{array}{l}\text { Urban BF } \\
\text { Median } \\
\text { (mo) }\end{array}$ & $\begin{array}{c}\text { Urban BF } \\
\text { Delta } 3 \\
\text { (mo) }\end{array}$ & $\mathrm{R}-\mathrm{U}^{4}(\mathrm{mo})$ & $\begin{array}{c}\text { R-U BF } \\
\text { Delta3 } \\
\text { (mo) }\end{array}$ \\
\hline Bolivia 1989 & 3,548 & 51.5 & 16.4 & - & 17.5 & - & 14.3 & - & +3.2 & - \\
\hline Bolivia 1994 & 3,614 & 47.6 & 17.6 & +1.2 & 18.9 & +1.4 & 15.7 & +1.4 & +3.2 & 0 \\
\hline Bolivia 1998 & 4,106 & 43.0 & 17.5 & +1.1 & 19.1 & +1.6 & 16.4 & +2.1 & +2.7 & -0.5 \\
\hline Brazil 1986 & 1,960 & 34.7 & 5.2 & - & 6.8 & - & 4.6 & - & +2.2 & - \\
\hline Brazil 1996 & 2,865 & 24.4 & 7.0 & +1.8 & 8.9 & +2.1 & 6.7 & +2.1 & +2.2 & 0 \\
\hline Colombia 1986 & 1,604 & 39.5 & 8.2 & - & 12.0 & - & 6.1 & - & +5.9 & - \\
\hline Colombia 1990 & 2,301 & 32.4 & 9.0 & +0.8 & 10.2 & -1.8 & 7.9 & +1.8 & +2.3 & -3.6 \\
\hline Colombia 1995 & 3,077 & 35.5 & 11.3 & +3.1 & 13.0 & +1.0 & 10.0 & +3.9 & +3.0 & -2.9 \\
\hline Dominican & 2,664 & 41.8 & 7.1 & - & 7.6 & - & 6.9 & - & +0.7 & - \\
\hline \multicolumn{11}{|l|}{ Republic 1986} \\
\hline $\begin{array}{l}\text { Dominican } \\
\text { Republic } 1991\end{array}$ & 2,397 & 41.2 & 5.8 & -1.3 & 8.3 & +0.7 & 4.6 & -2.3 & +3.7 & +3.0 \\
\hline $\begin{array}{l}\text { Dominican } \\
\text { Republic } 1996\end{array}$ & 2,653 & 41.7 & 7.6 & +0.5 & 10.7 & +3.1 & 6.2 & -0.7 & +4.5 & +3.8 \\
\hline Ecuador 1987 & 1,861 & 49.6 & 13.4 & NA & 14.9 & NA & 11.9 & NA & +3.0 & NA \\
\hline Guatemala 1987 & 2,797 & 73.0 & 20.5 & - & 20.8 & - & 19.1 & - & +1.7 & - \\
\hline Guatemala 1995 & 5,648 & 67.9 & 19.8 & -0.7 & 20.4 & -0.4 & 19.0 & -0.1 & +1.4 & -0.3 \\
\hline Guatemala 1998 & 2,751 & 61.8 & 19.9 & -0.6 & 20.4 & -0.4 & 18.6 & -0.5 & +1.8 & +0.1 \\
\hline Haiti 1994 & 2,147 & 67.9 & 17.5 & NA & 18.4 & NA & 15.2 & NA & +3.2 & NA \\
\hline Mexico 1987 & 3,412 & 38.4 & 8.1 & NA & 13.9 & NA & 5.0 & NA & +8.9 & NA \\
\hline Nicaragua 1997 & 4,637 & 47.3 & 12.2 & NA & 16.3 & NA & 9.3 & NA & +7.0 & NA \\
\hline Paraguay 1990 & 2,426 & 54.7 & 10.9 & NA & 13.1 & NA & 7.8 & NA & +5.3 & NA \\
\hline Peru 1986 & 1,796 & 47.8 & 15.4 & - & 19.4 & - & 10.8 & - & +8.6 & - \\
\hline Peru 1992 & 4,960 & 39.8 & 17.3 & +1.9 & 19.9 & +0.5 & 14.2 & +3.4 & +5.7 & -2.9 \\
\hline Peru 1996 & 9,188 & 41.6 & 19.5 & +4.1 & 20.2 & +0.8 & 18.6 & +7.8 & +1.6 & -7.0 \\
\hline $\begin{array}{l}\text { Trinidad \& } \\
\text { Tobago } 1987\end{array}$ & 1,138 & 56.8 & 6.0 & NA & 5.8 & NA & 6.4 & NA & -0.6 & NA \\
\hline
\end{tabular}

$\mathrm{NA}=$ not applicable.

1 weighted sample size.

2 percent sampled from rural areas based on weighted sample sizes.

3 Delta: difference in median BF duration across time in relation to first survey wave.

4 R-U: difference in median BF duration between rural $(\mathrm{R})$ and urban $(\mathrm{U})$ areas.

Dominican Republic, this delta increased across time (range: +0.1 months in Guatemala, +3.8 months in the Dominican Republic). In Brazil, the $\mathrm{R}-\mathrm{U}$ delta did not change during the target period (Table 2).

\section{- Level of education}

In five of the six countries examined, breastfeeding duration declined from the mid-1980s to the mid-1990s among women without formal education (BF delta range: -3.3 months in Brazil to -0.1 months in Peru). The only country with an increase in BF duration among women with no schooling was Bolivia, with a BF duration delta of +2.7 months. By contrast,
BF duration increased across time in all six countries among women with at least secondary education (BF delta range: +0.9 months in the Dominican Republic to +7.8 months in Peru). The same trend towards increased BF duration from the mid-1980s to the mid-1990s was found in all countries among women with a primary education (BF delta range: +0.2 months in Guatemala to +1.9 months in Colombia) (Table 3).

In all countries, the difference in the "no education/at least some secondary education" (N-S) differential in BF duration decreased in the mid-1990s as compared to the mid-1980s ( $(\mathrm{N}-\mathrm{S})$ BF delta range: -7.9 months in Peru to -0.4 months in Bolivia) (Table 3). 
Table 3

Breastfeeding (BF) time trends and differentials based on maternal level of education in 12 Latin American and Caribbean countries

Current status estimates based on children less than three years of age.

\begin{tabular}{|c|c|c|c|c|c|c|c|c|}
\hline \multirow[t]{2}{*}{ Country/survey year } & \multicolumn{2}{|c|}{ None } & \multicolumn{2}{|c|}{ Primary } & \multicolumn{2}{|c|}{ Secondary or higher } & \multicolumn{2}{|c|}{$\mathrm{N}-\mathrm{S}^{3}$} \\
\hline & $\begin{array}{l}\text { BF Median } \\
\text { mo }(n)^{1}\end{array}$ & $\begin{array}{c}\text { BF Delta2 } \\
\text { mo }\end{array}$ & $\begin{array}{c}\text { BF Median } \\
\text { mo (n) }\end{array}$ & $\begin{array}{c}\text { BF Delta } \\
\text { mo }\end{array}$ & $\begin{array}{c}\text { BF Median } \\
\text { mo (n) }\end{array}$ & $\begin{array}{l}\text { BF Delta } \\
\text { mo }\end{array}$ & Mo & $\begin{array}{c}\text { BF Delta } \\
\text { mo }\end{array}$ \\
\hline Bolivia 1989 & $17.8(711)$ & - & $17.0(1,824)$ & - & $13.1(1,013)$ & - & 4.7 & - \\
\hline Bolivia 1994 & $20.7(513)$ & +2.9 & $17.5(1,757)$ & +0.5 & $15.8(1,344)$ & +2.7 & 4.9 & 0.2 \\
\hline Bolivia 1998 & $20.5(456)$ & +2.7 & $18.1(1,965)$ & +1.1 & $16.2(1,684)$ & +3.1 & 4.3 & -0.4 \\
\hline Brazil 1986 & $9.1(248)$ & - & $4.8(1,373)$ & - & $5.3(336)$ & - & 3.8 & - \\
\hline Brazil 1996 & $5.8(189)$ & -3.3 & $6.5(1,122)$ & +1.7 & $7.3(1,554)$ & +2.0 & -1.5 & -5.3 \\
\hline Colombia 1986 & $13.1(120)$ & - & $10.7(915)$ & - & $6.0(569)$ & - & 7.1 & - \\
\hline Colombia 1990 & $12.8(128)$ & -0.3 & $9.7(1,089)$ & -1.0 & $6.5(1,083)$ & +0.5 & 6.3 & -0.8 \\
\hline Colombia 1995 & $12.2(144)$ & -0.9 & $12.6(1,297)$ & +1.9 & $10.0(1,636)$ & +4.0 & 2.2 & -4.9 \\
\hline Dominican Republic 1986 & $15.9(171)$ & - & $8.2(1,763)$ & - & $4.4(730)$ & - & 11.5 & - \\
\hline Dominican Republic 1991 & $16.6(190)$ & +0.7 & $6.9(1,283)$ & -1.3 & $4.1(920)$ & -0.3 & 12.5 & +1.0 \\
\hline Dominican Republic 1996 & $14.2(229)$ & -1.7 & $8.2(1,453)$ & 0 & $5.3(972)$ & +0.9 & 8.9 & -2.6 \\
\hline Ecuador 1987 & $15.0(199)$ & NA & $14.4(1,053)$ & NA & $11.7(609)$ & $\mathrm{NA}$ & 3.3 & NA \\
\hline Guatemala 1987 & $22.2(1,375)$ & - & $18.8(1,222)$ & - & $10.1(200)$ & - & 12.1 & - \\
\hline Guatemala 1995 & $22.2(2,160)$ & 0 & $19.0(2,774)$ & +0.2 & $10.5(714)$ & +0.4 & 11.7 & -0.4 \\
\hline Guatemala 1998 & $21.4(880)$ & -0.8 & $19.0(1,445)$ & +0.2 & $13.6(426)$ & +3.5 & 7.8 & -4.3 \\
\hline Haiti 1994 & $18.8(1,019)$ & $\mathrm{NA}$ & $17.0(872)$ & NA & $8.0(257)$ & $\mathrm{NA}$ & 10.8 & NA \\
\hline Mexico 1987 & $18.1(493)$ & NA & $9.3(2,022)$ & NA & $4.4(897)$ & NA & 13.7 & NA \\
\hline Nicaragua 1997 & $17.6(973)$ & NA & $13.3(2,161)$ & NA & $8.5(1,502)$ & NA & 9.1 & NA \\
\hline Paraguay 1990 & $18.0(86)$ & NA & $11.9(1,715)$ & NA & $7.1(624)$ & NA & 10.9 & NA \\
\hline Peru 1986 & $22.5(293)$ & - & $18.3(819)$ & - & $10.5(684)$ & - & 12.0 & - \\
\hline Peru 1992 & $21.5(498)$ & -1.0 & $19.3(1,987)$ & +1.0 & $13.3(2,474)$ & +2.8 & 8.2 & -3.8 \\
\hline Peru 1996 & $22.4(903)$ & -0.1 & $19.9(3,653)$ & +1.6 & $18.3(4,632)$ & +7.8 & 4.1 & -7.9 \\
\hline Trinidad \& Tobago 1987 & $11.5(9)$ & NA & $6.2(544)$ & NA & $5.8(584)$ & NA & 5.7 & NA \\
\hline
\end{tabular}

$\mathrm{NA}=$ not applicable.

1 weighted sample size.

2 Delta: difference in median BF duration across time in relation to first survey wave.

3 N-S: difference in median BF duration between women with no education (N) and women with at least secondary education (S).

\section{Discussion}

The most important finding in this study was the confirmation (with data from the 1990s) of a continuing trends towards increased breastfeeding duration in Latin America that had been documented since the 1970s (Monteiro et al., 1987; Trussell et al., 1992; Venancio \& M onteiro, 1998). Of the six countries where time trends could be examined, only Guatemala did not show an increase, perhaps due to a ceiling effect, since Guatemala al ready had the longest BF duration among the 12 countries included in the analyses. The findings are indeed encouraging, since this is happening at a time when one would have predicted a decline rather than an increase in breastfeeding duration, i.e., during this same period Latin America has been deeply immersed in the epidemiological and demographic transition character- ized by increased levels of urbanization, maternal education, and maternal employment outside the home, all of which have been inversely associated with breastfeeding outcomes in developing countries (Grummer-Strawn, 1996, Pérez-Escamilla, 1994).

An important question then becomes: What explains the observed increases in breastfeeding duration? Although the answers to this question are unknown, several hypotheses can be formulated. First, breastfeeding promotion efforts in the region may have had an impact (Elo \& Grummer-Strawn, 1993). One particular initiative that may be responsible for part of the increase in BF duration from the mid-1980s to the mid-1990s is the Baby Friendly Hospital Initiative (BFHI) launched by the United $\mathrm{Na}$ tions Children's Fund (UNICEF) in the late 1980s (Naylor, 2001). This initiative, based on fostering the implementation of ten key steps 
for the successful promotion of breastfeeding in maternity wards, is very likely to change breastfeeding behaviors (Pérez-Escamilla et al., 1994) and would be expected to have a stronger impact in urban than in rural areas and by consequence among women with higher levels of education. Indeed, the analyses presented clearly show that the improvements in BF duration across time tended to be stronger in urban than in rural areas and, in agreement with Trussell et al. (1992) and Monteiro et al. (1987), among women with more schooling. Although this hypothesis would explain changes in BF duration from the mid-1980s to the mid-1990s, it does not explain the urban gains in breastfeeding duration that also took place from the 1970 s to the 1980s (i.e., before the BFHI was launched on a massive scale). It is possible that national BF promotion policies and program efforts in the region (Elo \& Grummer-Strawn, 1993; Jelliffe \& Jelliffe, 1988) were strong enough before the BFHI to begin making a difference in both urban and rural areas. One outstanding example during this period was the adoption of the World Health Organization code for marketing of breast milk substitutes (WHO, 1981).

A second hypothesis is based on possible changes in infant feeding practices that resulted from the massive migrations that have taken place from rural to urban areas in Latin America since the 1970s. One positive influence that rural populations may have brought to urban areas is the contextual support necessary for urban-based breastfeeding promotion efforts to succeed. However, Trussell et al. (1992) have demonstrated that increases in breastfeeding duration from the 1970s to 1980s in several developing countries applied not only to women who migrated from rural to urban areas but also to women born in urban areas. Thus, this hypothesis may explain some but not all of the increases observed in urban areas of Latin America.

Results from these analyses show that although women in rural areas continue to breastfeed longer than their urban counterparts, this differential is decreasing across time in most countries examined. Furthermore, there is a very high country-level correlation between breastfeeding duration in urban and rural areas. This may be explained by the ever-increasing exchange and contact between rural and urban areas, which may result partially from secular trend towards "globalization", better roads and telecommunication systems and infrastructures.

More schooling continues to be associated with shorter breastfeeding. However, this dif-
Figure 1

Association between maternal level of education and likelihood of children ever being breastfed in Brazil ( $p<0.05, n=3,733$ ).

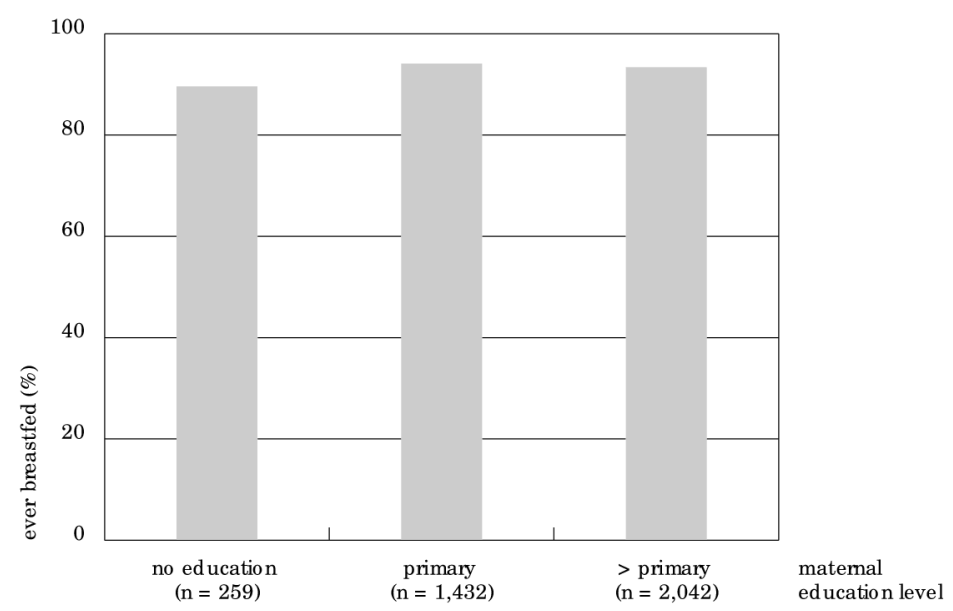

Source: Brazil-1996 Demographic and Health Survey.

ferential is decreasing over time in some countries like Brazil, where the direction of this association may al ready be reversing (i.e., as in the United States and other industrialized nations, women with higher levels of education have improved breastfeeding outcomes when compared with their less educated counterparts). The case of Brazil and other countries examined raises the concern that breastfeeding duration may be declining among the most disadvantaged groups (e.g., women with the least schooling) that stand to lose the most in terms of maternal and child health when this form of infant feeding is abandoned. Thus, the influence of education and income on breastfeeding behaviors and how it has changed across time in our region needs to be carefully examined. This relationship is undoubtedly complex, as Monteiro et al. (2001) have elegantly shown with regards to the obesity epidemic in Brazil. Cross-sectional national survey data (such as those from DHS) are very useful to document time trends in infant feeding behaviors in populations or large population subgroups. However, to further understand how caretaker's education level is related to infant feeding behaviors it is essential to conduct smaller-scale prospective hypothesis-testing studies.

In conclusion, the continuing improvement in breastfeeding duration still detected in the 
mid-1990s in Latin America and the Caribbean is one of the few positive nutrition-related outcomes that can be reported during the nutrition, epidemiological, and demographic transition that is taking place in our region. In fact, the aggressive steps taken to protect and promote breastfeeding in the region should be taken as a model by those trying to slow down negative behaviors and health outcomes associated with the nutrition transition, including the obesity epidemic (Martorell et al., 1998). As Popkin et al. (1991) showed in Honduras, these improvements are likely to be explained at least in part by massive and well-planned and well-executed national breastfeeding policies and promotion programs. Most such programs began as small-scale efforts by concerned individuals who foresaw the potentially enormous public health losses for the world if nothing was done to prevent the expected declines in breastfeeding in an increasingly urbanized world, where women's participation in the for- mal labor sector was increasing (Rea et al., 1999). The contribution of such improved breastfeeding practices during the nutrition transition is likely to be of a serious magnitude as breastfeeding is likely to protect individuals against both infectious and chronic diseases during childhood and/or later in life. It is known that exclusive breastfeeding for the first six months of life maximizes the benefits that breastfeeding (which should continue until the infant is two years of age or older) has to offer. The promotion of this infant feeding method is likely to lead to significant reductions in infant mortality in Latin America and the Caribbean (Betran et al., 2001). It is indeed our challenge to start seriously investing and concentrating on how to promote exclusive breastfeeding in our region. This infant feeding method is still rare (Labbok et al., 1997), but we have already gained a good understanding as to how to promote it in a cost-effective manner (Horton et al., 1996; Lutter et al., 1997; Morrow et al., 1999).

\section{References}

BARCELÓ, A. \& RAJPATHAK, S., 2001. Incidence and prevalence of diabetes mellitus in the Americas. Pan American Journal of Public Health, 10:300308.

BETRAN, A. P.; DE ONIS, M.; LAUER, J. A. \& VILLAR, J., 2001. Ecological study of effect of breastfeeding on infant mortality in Latin America. BMJ, 323: 303-306.

BROWN, K. H.; BLACK, R. E.; DE ROMANA, G. L. \&DE KANASHIRO, H. C., 1989. Infant-feeding practices and their relationship with diarrheal and other diseases in Huascar (Lima) Peru. Pediatrics, 83:31-40.

CESAR, J. A.; VICTORA, C. G.; BARROS, F. C.; SANTOS, I. S. \& FLORES, J. A., 1999. Impact of breast feeding on admission for pneumonia during post neonatal period in Brazil: Nested case-control study. BMJ, 318:1316-1320.

DIETZ, W. H., 2001. Breastfeeding may help prevent childhood overweight. JAMA, 285:2506-2507.

ELO, I. T. \& GRUM MER-STRAWN, L. M., 1993. Changes in breast-feeding initiation and duration in Peru, 1977-1986. Social Biology, 40:224-243. 
GRUMMER-STRAWN，L. M., 1996. The effect of changes in population characteristics on breastfeeding trends in fifteen developing countries. International Journal of Epidemiology, 25:94-102.

HORTON, S.; SANGHVI, T.; PHILLIPS, M.; FIEDLER, J.; PEREZ-ESCAMILLA, R.; LUTTER, C.; RIVERA, A. \& SEGALL-CORREA, A. M., 1996. Breastfeeding promotion and priority setting in health. Health Policy and Planning, 11:156-168.

INSTITUTE FOR RESOURCE DEVELOPMENT/MACRO INTERNATIONAL, 1990. An Assessment of Demographic and Health Surveys-I: Data Quality. Calverton: Institute for Resource Development/ Macro International.

INSTITUTE FOR RESOURCE DEVELOPMENT/MACRO INTERNATIONAL, 1991. Proceedings of the Demographic and Health Surveys World Conference: August 5-7. Washington, DC: Institute for Resource Development/ Macro International.

JELLIFFE, D. B. \& JELLIFFE, E. F. P., 1988. Programmes to Promote Breastfeeding. New York: Oxford University Press.

LABBOK, M. H., 1999. Health sequelae of breastfeeding for the mother. Clinics in Perinatology, 26:491503.

LABBOK, M. H.; PEREZ-ESCAMILLA, R.; PETERSON, A. \& COLY, S., 1997. Breastfeeding and Child Spacing Country Profiles. Washington, DC: Institute for Reproductive Health.

LUTTER, C. K.; PEREZ-ESCAMILLA, R.; SEGALL, A.; SANGHVI, T.; TERUYA, K. \& WICKHAM, C., 1997. The effectiveness of a hospital-based program to promote exclusive breast-feeding among low-income women in Brazil. American Journal of Public Health, 87:659-663.

MARTORELL, R.; KHAN, L. K.; HUGHES, M. L. \& GRUM MER-STRAWN, L. M., 1998. Obesity in Latin American women and children. Journal of Nutrition, 128:1464-1473.

MONTEIRO, C. A.; CONDE, W. L. \& POPKIN, B. M., 2001. Independent effects of income and education on the risk of obesity in the Brazilian adult population. Journal of Nutrition, 131:881S-886S.

MONTEIRO, C. A.; ZUNIGA, H. P.; BENICIO, M. H.; REA, M. F.; TUDISCO, E. S. \& SIGULEM, D. M., 1987. The recent revival of breast-feeding in the city of São Paulo, Brazil. American Journal of Public Health, 77:964-966.

MORROW, A. L.; GUERRERO, M. L.; SHULTS, J.; CALVA, J. J.; LUTTER, C.; BRAVO, J.; RUIZ-PALACIOS, G.; MORROW, R. C. \& BUTTERFOSS, F. D., 1999. Efficacy of home-based peer counselling to promote exclusive breastfeeding: A randomised controlled trial. Lancet, 353:1226-1231.
NAYLOR, A. J., 2001. Baby-Friendly Hospital Initiative. Protecting, promoting, and supporting breastfeeding in the twenty-first century. Pediatric Clinics of North America, 48:475-483.

PEÑA, M. \& BACALLAO, J., 2001. La obesidad y sus tendencies en la region. Revista Panamericana de Salud Pública, 10:75-78.

PEREZ-ESCAMILLA, R., 1994. Breastfeeding in Africa and the Latin American and Caribbean region: The potential role of urbanization. Journal of Tropical Pediatrics, 40:137-143.

PEREZ-ESCAMILLA, R.; POLLITT, E.; LONNERDAL, B. \& DEWEY, K. G., 1994. Infant feeding policies in maternity wards and their effect on breast-feeding success: An analytical overview. American Journal of Public Health, 84:89-97.

POPKIN, B. M., 2001. The nutrition transition and obesity in the developing world. Journal of Nutrition, 131:871S-873S.

POPKIN, B. M.; CANAHUATI, J.; BAILEY, P. E. \& O'GARA, C., 1991. An evaluation of a national breast-feeding promotion programme in Honduras. Journal of Biosocial Science, 23:5-21.

REA, M. F.; VENANCIO, S. I.; BATISTA, L. E. \& GREIN$E R, T ., 1999$. Determinants of the breastfeeding pattern among working women in Sao Paulo. Journal of Human Lactation, 15:233-239.

TRUSSELL, J.; GRUMMER-STRAWN, L.; RODRIGUEZ, G. \& VANLANDINGHAM, M., 1992. Trends and differentials in breastfeeding behaviour: Evidence from the WFS and DHS. Population Studies, 46: 285-307.

VENANCIO, S. I. \& MONTEIRO, C. A., 1998. A tendência de prática da amamentação no Brasil nas décadas de 70 e 80. Revista Brasileira de Epidemiologia, 1:40-49.

WHO (World Health Organization), 1981. International code of marketing of breast-milk substitutes. WHO Chronicle, 35:112-117.

YUSUF, S.; REDDY, S.; OUNPUU, S. \& ANAND, S., 2001. Global burden of cardiovascular diseases. Part I: General considerations, the epidemiologic transition, risk factors, and impact of urbanization. Circulation, 104:2746-2753.

Submitted on March 6, 2002

Final version resubmitted on September 9, 2002

Approved on October 24, 2002 